\title{
The Historical Turn: How Chinese Buddhist Travelogues Changed Western Perception of Buddhism
}

\author{
MAX DEEG \\ Cardiff University \\ DeegM1@cardiff.ac.uk
}

Keywords: Faxian, Xuanzang, Yijing, William Jones, Buddhist travelogues

DOI: https://dx.doi.org/10.15239/hijbs.01.01.02

Abstract: Information about Buddhism was scarce and vague at best in the West until the beginning of the nineteenth century. The first Orientalists studying Indian sources had to rely on Hindu texts written in Sanskrit (e.g. Purānas) which portrayed the Buddha as an avatāra of the Hindu god Viṣnu. The situation changed with the discovery of the Pāli texts from Śrī Lañā through scholars like George Turnour and the decipherment of the Aśokan inscriptions through James Prinsep by which the historical dimension of the religion became evident. The final confirmation of the historicity of the Buddha and the religion founded by him was taken, however, from the records of Chinese Buddhist travellers (Faxian, Xuanzang, Yijing) who had visited the major sacred places of Buddhism in India and collected other information about the history of the religion. This paper will discuss the first Western translations of these travelogues and their reception in the scholarly discourse of the period and will suggest that the historical turn to which it led had a strong impact on the study and reception of Buddhism-in a way the start of Buddhist Studies as a discipline. 
Tn the year of 1786, in his third 'Anniversary Discourse' as the President of the Asiatick Society in Calcutta the 'arch-Orientalist' William Jones (1746-1794) ${ }^{1}$ stated: 'nor can we doubt that WOD or ODEN, whose religion, as the northern historians admit, was introduced into Scandinavia by a foreign race, was the same with BUDDH, whose rites were probably imported into India nearly at the same time, though received much later by the Chinese, who soften his name into FO.'2

Jones continues to speculate about 'an important point in the chronology of the Hindus, ... the precise appearance of [BUDDHA], real or imagined, in this Empire [i.e. India]', ${ }^{3}$ and concludes: 'we may fix the time of BUDDHA, or the ninth great incarnation of VISHNU, in the year one thousand and fourteen before the birth of CHRIST, or two thousand seven hundred and ninety-nine years ago.' ${ }^{\text {4 }}$

These quotations reflect three major points:

1. There was no notion of Buddhism as a historically developed religion in its own right that has spread from India across Asia.

2. The main sources for the study of Indian antiquity were the Hindu sources like the Purannas according to which the Buddha was an avatāra of the Hindu god Vișnu. ${ }^{5}$

1 On Jones, see Cannon, The Life and Mind of Oriental Jones; and Franklin, Orientalist Jones.

2 'The Third Anniversary Discourse, on the Hindus, delivered 2nd of February, 1786': Jones, The Works of William Jones, 28. Jones takes a similar stance in his fourth address from the year 1787 (on the Arabs) where he speculates that the Buddha came from Ethiopia, see Jones, The Works of William Jones, 42; Jones, The Works of William Jones, 291 (1788). On Jones' 'theology' in general see App, William Jones' Ancient Theology. On the pre-Jones reception of Buddhism see also Beinorius, 'Buddhism in the Early European Imagination', and on the Victorian reception see Almond, 'The Buddha in the West', and Almond, The British Discovery of Buddhism.

3 Jones, The Works of William Jones, 28.

4 Jones, 29. 
3. There was an obsession with chronology and historicity, despite the fact that the Buddha was not recognized as a historical figure.

In the year 1788 Jones published another article on Indian chronology which highlights the fascination, even obsession, of generations of scholars to come with historicity not only in the studies of the Indian past. ${ }^{6}$ In this article Jones struggles again with the question how the obviously different dates of Buddha of the Purānas and other sources-like e.g. the Buddhist dictionary Amarakośa-could be reconciled by assuming that there were two different Buddhas, an older one, the avatāra of Viṣnu, and a younger one who had tried 'to overset the whole system of the Brabmans,, thus, in a way, de-historisizing both.

By statements like this Jones paved the way for the supremacy of Hindu Sanskrit sources far into the first half of the nineteenth century which went hand in hand with a disregard of Buddhist sources and Buddhism as an object worth of serious scholarly studies. As a prototype of evolving positivist and historicist attitude already Jones complained about the unhistorical nature of the Indian sources, while still insisting on their value for historical studies:

That no Hindu nation, but the Cashmirians, have left us regular histories in their ancient language, we must ever lament; but from Sanscrit literature, which our country has the honour of having unveiled, we may still collect some rays of historical truth, though time and a series of revolutions have obscured that light, which we might reasonably expect from so diligent and ingenious a people. The numerous Puránas and Itihásas, or poems mythological and heroic, are

5 In the 7 th address (1790, on the Chinese) Jones calls the Buddha 'the BUDDHA of the Hindus': Jones, The Works of William Jones, 104; see also 107: 'the Bauddhas, indeed, were Hindus'.

6 'On the Chronology of the Hindus', Jones, The Works of William Jones, 281-313.

7 Jones, The Works of William Jones, 290. 
completely in our power; and from them we may recover disfigured, but valuable, pictures of ancient manners and governments; ...

In this context Buddhism was either regarded as an import from abroad or as a side-product of Hinduism. Horace Hayman Wilson (1786-1860), for example, in his typical pro-Brahminical and antiBuddhist style, thought that Buddhism had been brought to India from Central Asia, had become refined there and be re-exported outside of India. ${ }^{9}$ The last view, that Buddhism was derived from Hinduism, was not restricted to the emphasis of the Buddha as an avatāra of Viṣnu but also to Hindu influence on Buddhist teaching as far as it was known by the time. ${ }^{10}$ Henry Thomas Colebrooke (1765-1837), for example, completely relying on Hindu sources, opined that ' $[t]$ he Jainas and the Bauddhas ... have been originally Hindus', ${ }^{11}$ and that Buddhist doctrine was borrowed from the philosophical system of Sānkhya. ${ }^{12}$

The situation started to change in the thirties of the nineteenth century through the study of and making available of three new strands of sources which I would consider to be the beginnings of Buddhist Studies as a historical-critical academic discipline. One was the 'discovery' of the literature written in Pāli, ${ }^{13}$ the 'church language' of the Ceylonese Buddhists, particularly George Turnour's

8 'The Tenth Anniversary Discourse, on Asiatick History, civil and natural, delivered 28th of February, 1793', Jones, The Works of William Jones, 147.

9 Wilson, 'Abstract of the Content of the Dul-vá', 8: '... [the Tartars] brought with them the faith of Bud'dha, and communicated it to India, whence it returned to them improved by the scholarship of learned converts. It is very doubtful, if Bud'dhism ever prevailed extensively in central Hindustan, ...'

10 See Lopez, 'Buddha', and Lopez, From Stone to Flesh.

11 Colebrooke, Miscellaneous Essays, 378 ('On the Philosophy of the Hindus. Part V: On Indian Sectaries', originally published 1824).

12 Colebrooke, Miscellaneous Essays, 103 and 111 ('On the Védas, or Sacred Writings of the Hindus', originally published 1805).

13 In 1791 (Jones, The Works of William Jones, 122) realized the affinity between Sanskrit and Pāli, as the canonical language of the Burmese (Ava), but still maintained that the 'Bauddhas' were originally Hindus. 
(1799-1843) publication and translation of the Pāli-Buddhist historiography Mahāvamsa ('Great Chronicle'). ${ }^{14}$ It was also Turnour who first pointed out the identity of the Greek Sandrakottos and Candragupta Maurya identified the king Piyadāsi Devānampiya of the rock inscriptions as the third Mauryan king Aśoka.

The other 'discovery' was the decipherment of the autochthonous Indian scripts Brāhmī and Kharoșțī through James Prinsep (1799-1840) $)^{15}$ and others which enabled scholars to read the numismatic and epigraphic sources, particularly the earliest specimens of Indian writing, the inscriptions of the Mauryan emperor Aśoka, which quickly established a sound basis for early Indian chronology and history.

The third pool of texts used for establishing the historicity of the Buddha and Buddhism as an original Indian religion were coming from outside of India. These were the records of early medieval Chinese Buddhist monks like Faxian 法顯 (ca. 340-420), Song Yun 宋雲 (beginning of the sixth century), Xuanzang 玄牀 (600 or 603-664), Yijing 義淨 (635-713) and others who had travelled to India in search of the Buddhist dharma. It is within this triangle of sources that Buddhist studies quickly developed into a true academic discipline in the nineteenth century's positivist tenets with its strong focus on historicity. The first two discoveries established a reliable chronology and the Chinese sources supported this by providing similar information and referring to places which marked the sites where the events presumably occurred. ${ }^{16}$

14 Turnour, An Epitome of the History of Ceylon, and Turnour, The Mahávanso.

15 See the collection of articles in Prinsep, Essays on Indian Antiquities, 1. On Prinsep's decipherment of Indian scripts see Salomon, Indian Epigraphy, 203. For the 'discovery' of Buddhism by colonialist British officers and administrators see Allen, The Buddha and the Sabibs.

16 See for example Barthélemy Saint-Hilaire, 'Caractère et vie de Çâkyamouni', 86, who points out the importance of Xuanzang's Record to confirm the dates and circumstance of the Buddha's parinirvana and the early history of the sangha (the first sangiti or council). 
This paper will concentrate on those texts which we are now used to call the Chinese Pilgrim Records. ${ }^{17}$ Nowadays we take more or less for granted, to some extent even quite uncritically, that these texts contain a lot of historical and geographical information about Buddhism in Central Asia and in India. ${ }^{18}$ However, this 'position' of the records was not established at the time when they were discovered and worked on, and their historical value was, for a short period between the late $30 \mathrm{~s}$ and late $50 \mathrm{~s}$ of the nineteenth century, quite disputed. In this paper I will attempt to follow the reception of their first translations which leads, together with the other discoveries and factors I have pointed out earlier, to what I would call the gradual 'historisization' of the study of Buddhism in the second half of the nineteenth century.

In the year 1833 the German Sinologist Karl Friedrich Neumann (1793-1817) ${ }^{19}$ published an article, 'Pilgerfahrten buddhistischer Priester von China nach Indien' ('Pilgrimages of Buddhist Priests from China to India'), in which he discussed the respective Chinese sources and translated parts of the early sixth century record of Song Yun, a text incorporated in the Luoyang qielan ji 洛陽伽藍記 ( $T$ no. 2092) ['Record of Monasteries in Luoyang']. At that time Jean-Pierre Abel Rémusat (1788-1832), ${ }^{20}$ the first professor of Sinology in Paris, had already worked for some time and before his death on his translation of Faxian's record, the Foguo ji 佛國記 ( $T$ no. 2085) ['Record of Buddhist Kingdoms'], which was then published posthumously in the year 1836 as the first full translation of one of the travelogues.

A table of the translationes principis of these Chinese Buddhist records (until the end of WW II) demonstrates that most of the work

17 For a discussion of the texts as genres see Deeg, 'When Peregrinus is not Pilgrim'.

18 Thus, de Jong, A Brief History of Buddhist Studies, 26, in his overview of Buddhist Studies, after a very long and detailed discussion of other early scholars' work, is very brief in his discussion of the Chinese records: 'Of great importance for the study of Indian Buddhism is the work done by Sinologists. Abel Rémusat, ..., translated Fa-hsien's Fo-kuo-chi. ... His successor, Stanislas Julien, translated the life of Hsüan-tsang and his Hsi-yü-chi (...)'.

19 On Neumann, see Walravens, Zur Geschichte der Ostasienwissenschaften, 173.

20 Walravens, Zur Geschichte der Ostasienwissenschaften, 13. 
in the first part of the nineteenth century was done by French scholars (Table 1):

TABLE 1 List of translated Chinese Buddhist records.

\begin{tabular}{|c|c|c|}
\hline Year & Scholar(s) & Title \\
\hline 1836 & Abel Rémusat & Fоӗ Kоиӗ Ki \\
\hline 1853 & Stanislas Julien & Histoire de la vie de Hiouen-Thsang \\
\hline $1857-1858$ & Stanislas Julien & Mémoires sur les contrées occidentales \\
\hline 1869 & Samuel Beal & Travels of Fah-Hian and Sung-Yun \\
\hline 1884 & Samuel Beal & $S i-Y u-K i$ \\
\hline 1886 & James Legge & A Record of Buddhistic Kingdoms \\
\hline 1888 & Samuel Beal & The Life of Hiuen-Tsiang \\
\hline 1894 & Édouard Chavannes & $\begin{array}{l}\text { Mémoire composé à l'époque de la Grande } \\
\text { Dynastie T'ang sur les religieux éminents }\end{array}$ \\
\hline 1895 & $\begin{array}{l}\text { Sylvain Lévi \& Édouard } \\
\text { Chavannes }\end{array}$ & 'L'itinéraire d'Ou-K’ong (751-790)' \\
\hline 1896 & Takakusu Junjirō & A Record of the Buddhist Religion \\
\hline 1903 & Édouard Chavannes & 'Voyage De Song Yun’ \\
\hline $1904-1905$ & Thomas Watters & On Yuan Chwang's Travels \\
\hline 1923 & Herbert A. Giles & The Travels of Fa-bsien \\
\hline 1938 & Walter Fuchs & Huei-ch'ao's Pilgerreise \\
\hline
\end{tabular}

The predominance of the French, not only in translating the Chinese travelogues, but also in Buddhist Studies in general at that time with scholars like Eugène Burnouf (1801-1852) as leading figures, is obvious. ${ }^{21}$ It certainly had to do with a set of circumstances, one

21 On Burnouf, see Yuyama, Eugène Burnouf, and Lopez, 'Introduction'. 
of them being the British natural focus on the past of their Indian subjects and the existing texts from antiquity which were Hindu Sanskrit texts, and a certain neglect of Chinese studies in Great Britain in that period which was only mended in the second half of the nineteenth century. The first French translations of Faxian's and Xuanzang's reports by Rémusat and Julien were met with some reservation by British scholars, a view that was overcome quickly by the obvious value of the texts and the historical information which they contained and delivered.

While Neumann's first attempt to introduce these Chinese sources to the scholarly readership was not successful, one of the first references - if not the first at all-to the Chinese Buddhist travellers and their reports in the English-speaking world in form of a review of Rémusat's translation of the oldest of the Chinese records, Faxian's travelogue, was made by the Indologist Horace Hayman Wilson, the first holder of the Boden Chair of Sanskrit at Oxford University (since 1832) and director of the Royal Asiatic Society (since 1837), in first issue of the fifth volume of the Journal of Royal Asiatic Society from the year 1839. It, as to be expected from a stern representative of Hindu matters with a not-always-concealed disrespect for Buddhism and the value of its sources for historical studies, ${ }^{22}$ acknowledged the value of the work in a rather reluctant way:

The accounts which [Faxian] gives are such as might be expected from his religious character, and, to say the truth, are somewhat meager, relating almost exclusively to the condition in which the religion of Buddha existed at the different places which he visited. ${ }^{23}$

Wilson also mentions Xuanzang's record, the Datang xiyu ji 大唐 西域記 ( $T$ no. 2087) ['Record of the Western Regions of the Great

22 See for example Wilson, 'Abstract of the Content of the Dul-vá', 6: 'Any thing like real chronology is, if possible, more unknown in Baud'dha than Brahmanical writings; and it is in vain therefore to expect any satisfactory specification of the date at which the Buddha SA'KYA flourished.'

23 Wilson, 'Account of the Foe Kúe Ki', 108. 
Tang'], of which he knew through an overview given by the French orientalist Ernest Augustin Xavier Clerc de Landresse (1800-1862), and states that 'it would be an object worthy of this Society to procure the original from China, if possible, and contribute to its translation.', ${ }^{24}$ a wish that was only fulfilled almost half a century later by Samuel Beal's translation.

In the second issue of the sixth volume of the Society's Journal (1841) William Henry Sykes (1790-1872), at that time a retired colonel-according to the quoted article a Lieutenant-Colonel-of the East India Company's troops and a director of the East India Company, published a very long and in some passages quite deviating and meandering discussion of Rémusat's translation of Faxian's travelogue in which he highlights, at the beginning, the historical value of this text much more dramatically than Wilson did two years before:

Our Sanskrit scholars have sought, in the depths of Brahmanical literature, for the means of illustrating the political, the religious, the moral, and the social condition of that ancient people, over whose minds it has hitherto been believed that Brahmans exercised from the earliest times unbounded sway. The inquirers sought for facts and they found fables; they looked for historic lights, and they found poetic coruscations, which served only to render the darkness in which truth was enveloped even more impenetrable. ... In this state of hopelessness, with respect to the means of elucidating the ancient history of India, there break upon us lights from the most unexpected sources-from the literature of that remarkable people, the Chinese-which will go far to dissipate the mists which have hitherto obscured our view, and will give our judgements a wider scope of action, and our deductions a more stable basis than we hitherto possessed. ${ }^{25}$

Sykes here clearly recognises the value of the Chinese record and highlights as the most important task of these sources to unveil the

\footnotetext{
24 Wilson, 'Account of the Foe Kúe Ki', 109.

25 Sykes, 'Notes on the Religious, Moral, and Political State', 248.
} 
ancient history of India rather than relying on unhistorical Indian sources. This positive assessment was not necessarily shared by all scholars working on Buddhism and its history. Eugène Burnouf, in his voluminous 'Histoire du Bouddhisme indien', first published in the year 1844, emphasizes the importance of the Buddhist Sanskrit sources recently sent to him by Brian Hodgson from Nepal for the study of Buddhism, the main aim of which was for the great French orientalist himself to explain the origins of the religion and its development in India. ${ }^{26}$ As a consequence Burnouf hardly makes use of Faxian's record available to him in Rémusat's translation; ${ }^{27}$ for him the work of the Hungarian Csoma de Cörös (Körosi Csoma Sándor, 1784-1842) on the Tibetan Buddhist texts, quite similar to what he himself was doing on the basis of the Sanskrit texts, was more valuable. ${ }^{28}$

The slowly growing recognition in the English-speaking and -writing scholarly community of the value of the Chinese records resulted in an English translation of Rémusat's book by J. W. Laidlay, published in 1848 , which the translator extended by some long notes on Indian matters in which he draws, as almost to be expected, on the 'expertise' of H. H. Wilson.

26 Burnouf, Introduction à l'histoire du Buddhisme indien, xxxvi: 'Une histoire du Buddhisme, pour être complete, devrait donc, après avoir expliqué l'origine de cette religion, et exposé les vicissitudes de son existence dans l'Inde, la suivre hors de sa terre natale, et l'étudier chez les peoples qui l'ont successivement receuillie.' ('For a history of Buddhism, therefore, to be complete, it should therefore, after having explained the origin of this religion and set forth the vicissitudes of its existence in India, follow it beyond its native soil and study it among the peoples who successfully received it.' English translation, 51.)

27 Burnouf only makes use of the Foguo ji in his discussion of the bodhisattva Mañjuśrī: Burnouf, Introduction à l'bistoire du Buddhisme indien, 34, and Introduction to the History of Indian Buddhism, 148. One wonders if Burnouf would have used Julien's translation of the Xiyu ji in the same negligent way if he had had the chance to consult it.

28 Burnouf, Introduction à l'bistoire du Buddhisme indien, 5; Burnouf, Introduction to the History of Indian Buddhism, 59. 
Strangely enough, in this first period of reception of the travelogues the high estimation as a historical source for Xuanzang's much longer and detailed report which prevailed from the middle of the nineteenth century until today was not in place, ${ }^{29}$ certainly also because Sykes, like Wilson before him, only knew the paraphrase of the Xiyu ji by Landresse. Of Xuanzang's record Sykes gives the following judgement:

[Xuanzang's] narrative has the drawback of being inflated and prolix. $\mathrm{He}$ is puerilely superstitious, and teems with absurd legends, and is altogether destitute of that simplicity and good faith which characterize Fa hian. ${ }^{30}$

In a lecture giving an overview of the research on the state of research of ancient Indian history and literature published in the Journal of the Royal Asiatic Society in 1852 Wilson, without having much more information about the content and historical context of Xuanzang's record than he had earlier, launched severe criticism:

Those who are interested in the history of India, however, look with anxious anticipation to the translation of M. Jullien [sic] of the travels of Hwan Tsang in India in the sixth and seventh centuries: it is said to be completed, but awaits some supplementary dissertations, as on the Buddhist chronology and the concordance of Sanskrit and Chinese names. In the meantime, a fragmentary memoir of Hwan Tsang, translated by M. Jullien [sic], has been communicated by him to the French Academy, and is separately printed. ${ }^{31}$ It is of very legendary - that is, of a very mendacious - character, and is not

29 The attempt of the British military officer William Anderson to show that Xuanzang's Record was influenced by Russian and Jesuit conspirators and therefore a fake is mentioned by Julien, Histoire de la vie de Hioun-Thsang, lxviii.

30 Sykes, 'Notes on the Religious, Moral, and Political State', 322.

31 It should be noted that four years later in the same journal in which another article by Wilson on the history of Buddhism appeared (Wilson, 'On Buddha and Buddhism') Julien (Julien, Extrait du Livre IV) published an extract of his translation of fascicle 4 of the Xiyu ji which clearly had the objective of silencing 
calculated to inspire any prepossession in favour of the authenticity of Hwan Tsang's travels. ${ }^{32}$

The bias of Wilson's remarks and his doubts about the authority of Xuanzang and the authenticity of his Record were rebuked by Julien himself a couple of months later in the introduction to his translation of the Xuanzang biography:

An Indologist who quite rightfully enjoys universal esteem has shown on the same subject [Xuanzang's record] —we regret to tell him this-a heavy-handedness and a haste which correspond badly to the normal moderation of his spirit and maturity of his judgement. We take the liberty to remind this illustrious Orientalist that the record of Hiouen-thsang was composed on imperial order in 648, and that it was already analysed in detail in the great encyclopaedia Fa-youen-chou-lin some years after the death of the author (in 669)so much for the age of the work. The courageous travels of the Buddhist monk are common knowledge in China and present themselves with the double authority of the contemporaneous biographies and the official historiographies of the Thang dynasty under which he lived. We would like to think that Mr. Wilson will make it his task to examine in a more conscious way the present work [i.e. the translation of the Biography] and that, after having read it with all the care he is able to, he will do more justice to Hiouen-thsang in order to rectify his first, rather unrestrained opinion about the truthfulness of this famous pilgrim and the authenticity of his journey which he has expressed a couple of months ago. ${ }^{33}$

the criticism against the historical value of the text: it contains information about the political history, for example, about the kings Mihirakula (Mahirakoula) and Bālāditya (Gupta).

32 Wilson, 'Lecture on the Present State', 213.

33 Abbreviated from Julien, Histoire de la vie de Hioun-Thsang, lxx.: 'Un indianiste, qui jouit en bon droit d'une estime universelle, a montré sur le même sujet [l'accueil de Xuanzang; MD], nous regrettons pour lui de le dire, une sévérité et precipitation qui répondent mal à la modération habituelle de son esprit et à la 
But old habits die hard. The harsh criticism which both he himself and Sykes had brought forward earlier is still echoed by Wilson in his 1860 summary of Stanislas Julien's translation of the Datang Xiyu ji when he deplores at the end of his article:

It is much to be regretted that our enterprising pilgrim should have devoted his inquiries so almost exclusively to the objects of his superstitious veneration, and have entered so little into details we should have infinitely preferred, respecting the social and political condition of India. ${ }^{34}$

This remark clearly reflects, besides being religiously and culturally biased, the typical historicist approach according to which only the historical facts counted that Wilson asked for-but could not provide, I am tempted to add, himself from his Hindu sources.

However, judgements like Wilson's and Sykes' did not prevail long, and Orientalists became aware of the importance of Xuanzang's

maturité de son jugement. Nous prendront la liberté de rapeller à cet illustre orientaliste, que la relation de Hiouen-thsang a été composée par ordre impériale en 648, et que peu d’années après la mort de l'auteur (en 669), elle se trouvait déjà analysée en détail dans la grande encyclopédie Fa-youen-chou-lin; voilà pour lâge de l'ouvrage. Quant aux pérégrinations courageuses du religieux bouddhiste, elle sont en Chine de notoriété publique, et se présentent avec la double garantie des biographies contemporaines et des Annales officielles de la dynastie des Thang, sous laquelle il a vécu. Nous aimons à penser que $\mathrm{M}$. Wilson se fera un devoir d'examiner conscieusement le présent ouvrage, et qu'après avoir lu avec toute l'attention dont il est capable, il sera assez juste envers Hiouen-thsang, pour rectifier le premier l'opinion peu mesurée qu'il a émise il ya quelques mois, sur la véracité de ce célèbre pèlerin et sur l'authenticité de son voyage.'

34 Wilson, 'Summary Review of the Travels of Hiouen Thsang', 137. Wilson also refers to 'rare, scattered, and meagre' 'notices of this nature' and the 'general description which is in the main correct' - he certainly means the first half of the second fascicle of the Xiyu ji, the general description of India-and promises to investigate this portion 'when I have leisure', a promise which he, to my knowledge—and one could add, fortunately—was not able to keep. 
Record and his Biography. Stanislas Julien, in his introductions to his translations of Biography and of the Record, states that he was prompted already in the year 1839 to translate the Record by Alexander von Humboldt (1769-1859) who therefore already must have had acquired some knowledge of the existence of and information about the text, probably through references in Rémusat's translation and notes. ${ }^{35}$

Already Karl-Friedrich Neumann, in his review of Rémusat's translation of Faxian's record from the year 1840, had expressed a view quite different than Wilson of both Faxian's and Xuanzang's records:

If India is the sun, then China is the moon which abundantly reflects the light to where it originated. If it is possible at all-and we allow ourselves to doubt it in the light of the latest researchto bring order, meaning and reason to the confusion of Indian myths and dynastic lineages this only can be done, in our firm opinion, through the dry and prosaic chronicles, through the records and travelogues of the Chinese, so rich in facts. ... Only China provides us with the sources to this highly rich and peculiar painting of the development of a great part of the Asian family of mankind. ${ }^{36}$

In the same article Neumann points out to the great value of the

35 Julien, Histoire de la vie de Hioun-Thsang, xiv; Julien, Mémoires sur les contrées occidentales, vi.

36 Neumann, Review of Foe Koue Ki, 105: 'Ist Indien die Sonne, so ist China der Mond, der in reichlicher Fülle das Licht dahin zurückstrahlt, wovon es ausgegangen. Ist es überhaupt möglich, woran wir nach den neuesten Forschungen uns noch zu zweifeln erlauben, Ordnung, Sinn und Verstand in das Gewirre indischer Mythen und Dynastienreihen zu bringen; so kann dies nur, dies ist unsere feste Überzeugung, durch die trockenen, nüchternen Chroniken, durch die an Thatsachen reichen Berichte und Reisebeschreibungen der Chinesen geschehen. ... China liefert uns einzig und allein die Quellen zu diesem höchst reichen merkwürdigen Gemälde der Entwicklungsgeschichte eines grossen Theils der asiatischen Menschenfamilie.' 
translation of Faxian's record and deplores the fact that no complete text of Xuanzang's Xiyu ji is available in Europe. ${ }^{37}$

The high opinion which not only Sinologists like Neumann, Rémusat and Julien but also students of Indian Buddhism had of the Chinese records in general and of Xuanzang's record in particular after the middle of the eighteenth century was definitely influenced by the already mentioned translation of Xuanzang's Datang xiyu ji by Stanislas Julien, Rémusat's successor on the Sinology chair in Paris. ${ }^{38}$ Julien had first translated the biography of Xuanzang

37 Neumann, Review of Foe Koue Ki, 151: 'Die Übersetzung und Erläuterung des Fo kuo ki, so viel man auch schon zu unseren, so viel man in künftigen Zeiten daran zu verbessern finden wird, machen Epoche in der E[rf]orschung über die Geschichte der Verbreitung der Lehre Schakiamunis, in der Kenntniss des esoterischen und exoterischen oder des metaphysischen und praktischen Buddhismus, in der Kunde des alten Indiens, während der Zeiten des fünften, sechsten und siebten Jahrhunderts. Niemand, der sich der Erforschung der Geschichte der Kultur Mittelund Ostasiens widmet, wird dieses Werk entbehren können. Eine höchste schätzenswerthe Zugabe zur Pilgerfahrt des Fa hien ist die Reiseroute des Hiuen tsang, der in der ersten Hälfte des siebten Jahrhunderts unserer Zeitrechnung von China aus nach Indien reiste, und in einem eigenen wie es scheint ziemlich ausführlichen Werke alle Länder Indiens und Mittelasiens, die er besuchte, geschildert hat. Die Beschreibung der westlichen Gegenden ( $i j u k i$ ) findet sich leider nicht vollständig in Europa.' ('As much as one may find improvable in our time as well as in the future, the translation and explanation of the Fo kuo ki are epoch-making in the research of the history of the spread of the teaching of Schakyamuni, of the knowledge of esoteric and exoteric or of metaphysical and practical Buddhism, of the knowledge of ancient India during the periods of the fifth, sixth and seventh centuries of our era. Nobody dedicated to the research on the cultural history of Middle and East Asia can do without this work. A highly valuable addendum to the pilgrim's record of Fa hien is the travel route of Hiuen tsang who travelled from China to India in the first half of the seventh century or our era and describes in his own, obviously quite detailed work all the countries of India and Middle Asia that he visited. Unfortunately the complete Description of the Western Regions (Si ju ki) is not found in Europe.')

38 The information given by Julien was not restricted to Faxian's and Xuanzang's records but was also drawn from Chinese Buddhist historiographical works like 
as the first in a planned series of translations called 'Travels of the Buddhist Pilgrims' ('Voyages des Pèlerins bouddhistes'). ${ }^{39}$ In the preface to this translation he had already emphasized the importance and authenticity of Xuanzang's travels and the content of the Record. ${ }^{40}$ His translations quickly replaced Rémusat's translation of the Foguo $j i$ in terms of importance as historical sources. ${ }^{41}$

Although at that time and nowadays the Xiyu ji is taken as an eyewitness record of Central Asia and India, Julien insisted that most of the text consisted of translations from Indian texts, which would give

the Shijia shipu 釋迦氏譜 [Genealogy of the Śākya Clan] (T no. 2041): Lassen, Indische Alterthumskunde. Zweiter Band, note 1.

39 Originally Julien also wanted to re-translate Faxian's Foguo ji (Julien, Mémoires sur les contrées occidentales, v), a plan that was never brought into realization. Included in the series would also have been Huiseng's and Song Yun's record, Yijing's Datang qiufa gaoseng zhuan 大唐西域求法高僧傳 (T no. 2066) ['Biographies of Eminent Monks Searching for the Dharma in the Western Regions of the Great Tang'], and Jiye's travelogue: Julien, Histoire de la vie de Hioun-Thsang, iv.

40 Julien, Histoire de la vie de Hioun-Thsang, lxvii: 'Si, ..., j’ai réussi à donner une idée complète de la longue peregrination de Hiouen-thsang dans les contrées de l'Ouest et dans l'Inde, non seulement on peut déjà presentir la très-haute importance de sa Relation pour l'histoire du bouddhisme et pour la connaissance géographique des pays visités, mais on peut juger aussi de la parfaite authenticité et de l'exactitude remarquable de ces documents où les détails de ce voyage nous ont été transmis.' ('If, ... I have succeeded in giving a complete idea of the long pilgrimage of Hiouen-thsang to the Western Regions and to India, then one cannot only anticipate the extreme importance of his Record for the history of Buddhism and for the geographical knowledge about the visited countries, but one may also valuate the perfect authenticity and the remarkable exactness of these texts where the details of this journey has been transmitted to us.') See also Julien's defense of Xuanzang against the criticism of reporting superstitious and legendary information rather than historical facts: Julien, Histoire de la vie de Hioun-Thsang, lxxii.

41 See Barthélemy Saint-Hilaire, 'Histoire de la vie et des ouvrages de Hiouenthsang', 412 . 
it even more authenticity and authority in respect to Indian history and topics: ${ }^{42}$

[...] until now a lot of scholars have considered [the Si-yu-ki] the original and personal record of Hiouen-thsang, but [it] has been redacted by a specific writer of the name Pien-ki relying on numerous documents translated from Sanskrit by the illustrious traveller and taken mostly from statistical and historical works as could have been produced in India and which do not exist anymore today. This has caused the editors to say that the work had been translated from Indian languages, although one cannot consider it a literal and continuous translation of a Sanskrit text because of the details of the travel route which one finds on every page. ${ }^{43}$

This change of esteem can be demonstrated through and in the monumental 'Indische Altertumskunde' of Christian Lassen (1800-1876), a student and successor of August Wilhelm Schlegel (1767-1845) to the Sanskrit chair at the University of Bonn. In the first edition (of the first two volumes) Lassen had to rely on Rémusat's translation of the Foguo ji, of which he was quite

42 This point is clearly made by Jules Barthélemy Saint-Hilaire (1805-1895) in his review of Julien's translation of the Biography which includes a preview of the translation of Xuanzang's Record published one year later: Barthélemy SaintHilaire, 'Histoire de la vie et des ouvrages de Hiouen-thsang', 157.

43 Julien, Mémoires sur les contrées occidentales, vi: '... beaucoup de savants avaient considéré [le $S i-y u-k i$ ] jusqu'ici comme la relation originale et personelle de Hiouen-thsang, mais [il], ..., a été rédigé par un écrivain distingué du nom de Pien-ki, à l'aide de nombreux documents traduits du sanscrit par l'illustre voyageur, et tirés, pour la plupart, d'ouvrages statistiques et historiques, tels qu'on pouvait les faire dans l'Inde, et qui n'existent plus aujourd'hui. C'est là ce qui a fait dire, à bon droit, par les éditeurs, que l'ouvrage était traduit des langues de l'Inde, quoique l'on ne puisse, en raison des details de l'itinéraire que l'on rencontre à chaque page, le considéré comme la traduction littérale et continue d'un texte sanscrite.' In the light between the obvious collaboration of both scholars it would be interesting to know if this view had been influenced by Lassen's similar opinion (see below). 
critical. ${ }^{44}$ But he also received direct advice from Julien, who obviously had been working on a complete text of Xuanzang's Datang Xiyu ji from the late 1830s. ${ }^{45}$ In the first edition of his monumental compendium, without having direct access to a full translation of the Datang Xiyu ji, Lassen was of the opinion that the Chinese travellers retrieved their detailed knowledge about Indian institutions and history from Indian historical sources which were then lost. ${ }^{46}$ Against the opinion of many of his colleagues he argued for a historiographic tradition of the ancient Indians the works of which became lost afterwards.

In the second edition of the second volume of his Indische Altertbumskunde, after the publication of Julien's translation of the Datang Xiyu ji, Lassen had changed to a much more positive view:

44 Lassen, Indische Alterthumskunde. Zweiter Band, 54.

45 See Julien, 'Examen critique', 406. The final version of the translation was, however, done between September 15 and October 30, 1854 (first six fascicles) and September 1 and October 30, 1855 (last six fascicles): Julien, Mémoires sur les contrées occidentales, xiv, note 1.

46 Lassen, Indische Alterthumskunde. Zweiter Band, 41: 'Daßs früher ausführliche Berichte über die Geschichte der Könige des innern Indiens da waren [inserted is a note about the Xiyu ji, M.D.], erhellt daraus, daßs solche von den Buddhisten über diejenigen aufbewahrt worden sind, welche entweder in der Geschichte der Religion eine hervorragende Rolle einnahmen oder sonst eine bedeutende Rolle gespielt hatten. Da nicht angenommen warden kann, daßs die Buddhisten allein von diesen Erzählungen Kenntnis besaßsen, sondern daßs sich auch den Brahmanen zugänglich waren, folgt, daßs es ihnen nicht an den Mitteln gefehlt habe, die frühere Geschichte ihres Landes zu kennen, wenn ihr Geist sich der Thätigkeit eine solche zu schreiben zugewendet hätte.' ('That there were earlier, more detailed records on the history of the kings of Inner India [...] becomes evident through the fact that these were preserved by the Buddhists about those who either had an eminent role in the history of the religion or played another important role. Since it cannot be assumed that only the Buddhist had knowledge of these stories but that they also were accessible to the brabmins we can conclude that they [i.e. the brabmins] were not lacking the means to know the early history of their country if their spirit had turned to the activity of writing it.') 
Unequally more qualified [than the Greek sources] to write authentic reports about India were the Chinese Buddhists who visited the home country of the founder of their religion and the sites sanctified by his deeds, who collected the sacred scriptures of their creed and wrote down their observations after their return to their home country. ${ }^{47}$

In volume 3 of his monumental work (Indische Alterthumskunde. Dritter Band) Lassen then highlights the value of Xuanzang's report for the study of Buddhism in Asia and the geographical information contained in the text, which is, according to Lassen, a 'pleasant contrast' to the 'quality (Beschaffenheit) of the [Indian] sources [which are] restricted to give dry facts like the succession of rulers, sacrifices, donations of land and general statements about victories and eulogies on the rulers and their ancestors. ${ }^{38}$

In the 'Appendices' (Anbaenge) to the Altertbumskunde, containing Chinese and Arabic sources on India, Lassen exclusively discusses information from the general description of India in the Datang Xiyu ji (first half of the second fascicle)_Faxian's Foguo ji obviously had been 'eliminated' for the reason of being an inferior source to Xuanzang. The 'function' of the Datang Xiyu ji becomes reduced to confirming what is described in and known from Indian sources and the text, ${ }^{49}$ as it were, 'enslaved' by the search of histor-

47 Lassen, Indische Alterthumskunde. Zweiter Band, second edition, 1874, 628.

48 Lassen, Indische Alterthumskunde. Dritter Band, 707.

49 This particularly concerns the parts about 'political history' ('politische Geschichte') which Lassen calls 'very appreciated additions to the autochthonous historical sources' ('sehr erwünschte Ergänzungen der einheimischen historischen Quellen'): Lassen, Indische Altertbumskunde. Anhang zum III. und $I V$, 1. See also Lassen, 2: 'Hiuen Tshang schickt seiner Beschreibung Indiens einen kurzen allgemeinen Bericht von Indischen Dingen voraus, der einerseits zwar beweist, wie genau der wissbegierige Pilger Indien in jeder Beziehung erforscht hat, andererseits aber größstenteils nur Bekanntes darbietet.' ('Hiuen Tshang begins his description of India with a brief and general record of things Indian which demonstrates, on the one hand, how exactly India was explored in 
ical authenticity. What interested Lassen most were the pieces of information which are different from and sometimes contradictory to the ones gained from the Indian sources (measurement of space and time, government, caste system, ordeals, funerary customs, etiquette), but instead of trying to explain these differences he treats them either as additional information or as misinterpretations or errors of the Chinese monk.

The alleged 'defect' of the Chinese travelogues - to be full of legends and imagination that could not be trusted historically-claimed and brought forward by Wilson and others had been mended. ${ }^{50}$ Instead a kind of 'Indianization' and historisization of the texts-clearly reflected already in Lassen's use of Xuanzang's record-was being established according to which the Chinese records were more reliable for establishing and researching the history of Buddhism or of early India in general, although they were reporting events that were centuries distant from their authors. In the second half of the nineteenth century this had become the credo of almost all researchers studying Indian Buddhism and its history. By the year 1884 Samuel Beal in the 'Introduction' to his still widely read and used English first translation of the Datang Xiyu ji, expresses this approach quite clearly:

The progress which has been made in our knowledge of Northern Buddhism during the last few years is due very considerably to the discovery of the Buddhist literature of China. This literature (...) contains, amongst other valuable works, the records of the travels

any possible way by the inquisitive pilgrim, but on the other hand mostly presents us with exclusively well-known facts.')

50 Barthélemy Saint-Hilaire, 'Histoire de la vie et des ouvrages de Hiouenthsang', 85, already relativised the value of the information contained in the Record: 'En interrogeant Hiouen-thsang sur l'histoire, il faut bien distinguer les faits qu'il peut attester pour les avoir observés lui-même, et ceux qu'il rapporte d'après les traditions plus ou moins authentiques.' ('If we ask Hiouen-thsang about history we must well distinguish between the facts which he is able to attest since he has observed them himself, and those which he reports according to more or less authentic traditions.') 
of various Chinese Buddhist pilgrims who visited India during the early centuries of our era. These records embody the testimony of independent eye-witnesses as to the facts related in them, and having been faithfully preserved and allotted a place in the collection of the sacred books of the country, their evidence is entirely trustworthy.

It would be impossible to mention seriatim the various points of interest in these works, as they refer to the geography, history, manners, and religion of the people of India. ... But there is one particular that gives a more than usual interest to the records under notice, and that is the evident sincerity and enthusiasm of the travellers themselves. ${ }^{51}$

If the Chinese records together with the Theravāda historiographic texts and the inscriptional material from India clearly helped to establish the historicity of the Buddha and Buddhism in terms of time and to bring some order to the chaos of Indian ancient chronology, the consolidation of Buddhist Studies as a historical discipline was achieved by showing that Buddhism existed as a reality in space as well. ${ }^{52}$ Already in 1856 Barthélemy Saint-Hilaire had seen the importance of the Chinese records in this respect, and had

51 Beal, $S i-Y u-K i$, ix. Includes translations of Faxian's and Songyun's report.

52 The direct link made between 'cultural geography' and history is, for example, traceable in Carl Ritter's (1779-1859) monumental work 'Die Erdkunde im Verhältnis zur Natur und Geschichte des Menschen oder allgemeine vergleichende Geographie als sichere Grundlage des Studiums und Unterrichts in physicalischen und historischen Wissenschaften' ('Erdkunde' in relation to the nature and history of humankind, or general comparative geography as a safe basis for the study and teaching of physical and historical sciences', published 1822); on Ritter and the role of the scientification of geography see Osterhammel, Die Verwandlung der Welt, 132 (English translation, 79). In one of his treatises on stūpas ('topes') Ritter, Die Stupa's (Topes), 129, refers continuously to Rémusat's recently published translation of Faxian's Foguo ji. But also Lassen starts his Indische Altertumskunde. Erster Band with an encyclopaedic overview of South-Asian and adjacent geography. Directly in connection with the Chinese travelogues this link between history and geography is reflected in Barthélemy 
foreseen what would start to happen a few years later: ${ }^{53}$

[...] all that story [of the life of the Buddha], so striking and so simple, was revived for the traveller in the monuments to which he paid his devotional reverence. We already know them [the monuments] all from the Lalitavistara, the Lotus of the Good Law, from the Buddhist sutras, from the Tibetan and Singhalese documents, etc. But through the report of Hiouen-thsang it [the story] attains a new level of authenticity which is henceforth equating certainty. The pilgrim is, without any doubts, through his own lifetime far from the events which he reports on the basis of his faith in the tradition; but the ruins which he studies one after the other and which Fa-hian had pointed out two centuries

Saint-Hilaire's extensive discussion of Julien's translation of Xuanzang's life and, anticipating the publication of Julien's translation of it, the Record (Barthélemy Saint-Hilaire, 'Histoire de la vie et des ouvrages de Hiouen-thsang').

53 Barthélemy Saint-Hilaire had already indicated the possibility to find the places - in the specific case the place of the bodhi-connected to the life of the Buddha with the help of the information from the Xiyu-ji and other sources two years earlier: Barthélemy Saint-Hilaire, 'Caractère et vie de Çâkyamouni', 413: 'Je n'hésite pas à penser qu’à l'aide des indications si précises que nous donnent le Lalitavistara, Fa-hian et Hiouen-thsang, il ne fût possible de retrouver Bodhimanda; et je ne serais pas étonné que quelque jour un de ces officiers de l'armée anglaise, si intelligents et si courageux, ne nous apprît qu'il a fait cette découverte; elle vaudrait certainement toutes les peines qu'elle aurait coûtées et que probablement on ne se donnerait pas en vain. La configuration des lieux n'a pas changé; et si les arbres ont péris, les ruines de tant de monuments doivent avoir laissé sur le sol des traces reconnaissables.' ('I do not hesitate to think that, with the help of such precise directions as the Lalitavistara, Fa-hian and Hiouenthsang give us, it should be possible to find Bodhimanda again; and I would not be surprised if, at one day, one of these officers of the English army, so intelligent and brave, were to inform us that he has made this discovery; it certainly would be worth all the trouble it would have cost which would not have been in vain. The layout of the places has not changed; and if the trees have disappeared the ruines of such monuments must have left recognizable traces on the ground.') 
before him are not very far from them [the events]. Most of these gigantic stūpas, built by Aśoka, even if they are not contemporary of the preaching of the reformer, are rather close to it. ... Let us add that these ruins which were visited in the 5th and 6th centuries by the two missionaries we have accounts of are still scattered across the ground nowadays, and that all the investigations of which they are today the object of curiosity, confirm entirely the minute details which Hiouen-thsang has reported. He will definitely contribute his fair share to their discovery; and I have no doubts ... that an intelligent traveller could still recover in India, with Hiouen-thsang's Record in his hand, all the places and the ruined monuments which he has described. ${ }^{54}$

The idea was that history and chronology can be supported by an almost unchanging spatial dimension of Buddhism, as expressed, again, by Barthélemy Saint-Hilaire:

54 Barthélemy Saint-Hilaire, 'Histoire de la vie et des ouvrages de Hiouenthsang', 88: '... toute cette histoire [de la vie du Bouddha] si frappante et si simple vit encore pour le voyageur dans les monuments auquels il porte ses dévots hommages. Nous les connaissons déjà toute entière par le Lalita vistara, par le Lotus de la Bonne Loi, par les Soûtras bouddhiques, par les documents tibétains et singhalais, etc. Mais elle acquiert, par le récit de Hiouen-thsang, un nouveau dégré d’authenticité, qui équivaut désormais à une certitude. Sans doute, le pèlerin est éloigné, par le temps où il vit, des événements qu'il rapporte sur la foi de la tradition; mais ces ruines, qu'il étudie une à une, et que Fa-hien avait signalées deux siècles avant lui, n'en sont pas très-loin. La plupart de ces stoûpas gigantesques, construits par Açoka, s'ils ne sont pas contemporains de la predication du réformateur, en sont assez rapprochés. ... Ajoutez que ces ruines, visitées dans le $\mathrm{v}^{\mathrm{e}}$ et vii ${ }^{\mathrm{e}}$ siècle par les deux missionaires dont nous possédons les relations, jonchent encore le sol à l'heure qu'il est, et que toutes les investigations dont elles sont aujourd'hui le curieux objet confirment pleinement les détails minutieux que Hiouen-thsang a consignés. Il contribuera certainement beaucoup pour sa part à les faire reconnaître; et je ne doute pas, ..., qu'un voyageur intélligent ne puisse actuellement, la relation de Hiouen-thsang à la main, retrouver dans l'Inde tous les lieux et tous les monuments ruinés qu'il a décrit.' 
Between the reign of Aśoka, no matter if one places it either 100 or 300 hundred years after the nirvanna of the Buddha, and the journey of Hiouen-thsang lies almost a thousand of years. Undoubtedly very serious events have happened in that long period; but it seems as if none of them was of the kind to have an impact on Buddhism. ${ }^{55}$

This is the one of the underlying motives of the first real archaeological or sometimes rather proto-archaeological activities of colonial officers and administrators which, again, cannot be unlinked from the Chinese travelogues. These men found and brought to light remains from the Indian past which could be identified clearly as the ones described in the Chinese travelogues - and suddenly Xuanzang's report gained, because of its sheer length but also due to its higher degree of details, an even more predominant position amongst the sources recognised as historical.

The reincarnated main driving force behind this kind of use of the pilgrims' records was Alexander Cunningham's (1814-1893) ${ }^{56}$ by whose archaeological 'raids' in Northern India, first with Stanislas Julien's French and later with Samuel Beal's English translation in his hands, the 'infallibility' of Xuanzang's 'Record of the Western Regions' as an historical source on India and Indian Buddhism was established. ${ }^{57}$ In his memorandum to the Governor General of India, Lord Charles Caning (1812-1862), from November 1861, which finally led to his appointment as the Archaeological Surveyor to the Government of India, Cunningham wrote with a clear appeal to the 'Classicist' ideology of the time:

55 Barthélemy Saint-Hilaire, 'Histoire de la vie et des ouvrages de Hiouenthsang', 93: 'Du règne d'Açoka, qu'on le place d'ailleurs cent ans ou trois cent ans après le Nirvâna du Bouddha, jusqu'au voyage de Hiouen-thsang, il y a près d'un millier d'années. Dans ce longue intervalle, il s'est passé, sans aucun doute, de très-graves événements dans l'Inde; mais il ne semble pas qu'aucun fût de nature à toucher le bouddhisme.'

56 On Cunningham, see Imam, Sir Alexander Cunningham, and Leoshko, Sacred Traces.

57 See particularly Cunningham, The Ancient Geography of India. 
In describing the ancient geography of India, the elder Pliny, for the sake of clearness, follows the footsteps of Alexander the Great. For a similar reason, in the present proposed investigation [i.e. the archaeological exploration of Northern India], I would follow the footsteps of the Chinese pilgrim Hwen Tshang, who, in the seventh century of our era, traversed India from west to east and back again for the purpose of visiting all the famous sites of Buddhist history and tradition. In the account of his travels, although the Buddhist remains are described in most detail with all their attendant legends and traditions, yet the number and appearance of the Brahmanical temples are also noted, and the travels of the Chinese pilgrim thus hold the same place in the history of India, which those of Pausanias hold in the history of Greek. ${ }^{58}$

Cunningham's approach set the tone for and the method of dealing with the Chinese travellers' records. The records were now even more doomed to replace the lack or scarcity of equivalent information from the Indian sources and historical contexts. They are and were, as a consequence, never studied in their own right-that is, as Chinese texts in their Chinese context-and free from the preconception of being historically descriptive of things Indian (or Central-Asian). The archaeological success of Cunningham and others achieved with the help of first Julien's and later Beal's translation of the Datang Xiyu $j i$ and the other Chinese records in their hands bound the text to the Indian soil. Although a historically critical approach to most other Buddhist sources has become the standard, in a certain way the Chinese travelogues were, in a way, denied their historical contexts and their Chinese-ness. ${ }^{59}$ They were therefore hardly scrutinized in and for their real historical value and according to modern criteria of higher text criticism and contextualisation. The historicity claimed for these texts starting around the middle of the nineteenth century when they were discovered fired back as they became, in a way, fossils without room for change in meaning and interpretation.

\footnotetext{
58 Cunningham, Four Reports, iv.

59 See, for example, Deeg, "“Tis all Here”,
} 


\section{Bibliography}

Allen, Charles. The Buddha and the Sabibs. The Men who Discovered India's Lost Religion. London: John Murray, 2002.

Almond, Philip C. The British Discovery of Buddhism. Cambridge: Cambridge University Press, 1988.

- - - 'The Buddha in the West: From Myth to History'. Religion 16, no. 4 (1986): 305-22.

App, Urs. The Birth of Orientalism. Philadelphia: University of Pennsylvania Press, 2010.

- - - The Cult of Emptiness: The Western Discovery of Buddhist Thought and the Invention of Oriental Philosophy. Rorschach, Kyoto: University Media, 2012.

- - - William Jones' Ancient Theology. Sino-Platonic Papers 191, July 2009. Advanced online publication. http://sinoplatonic.org/complete/spp191_william_jones_orientalism. pdf.

Barthélemy Saint-Hilaire, Jules. 'Caractère et vie de Çâkyamouni' [Character and life of Śākyamuni]. Journal des savants [Journal of scholars] (Juillet 1854): 409-26.

- _ - 'Histoire de la vie et des ouvrages de Hiouen-thsang et de ses voyages dans l'Inde, depuis l'an 629 jusqu'en 645 (de notre ère), par Houeï-li et Yen-thsong, suivie de documents et d'éclaircissements géographiques tirés de la relation originale de Hiouen-thsang, traduite du chinois par Stanislas Julien, member de l'Institut de France' [Story of the life and works of Hiouenthsang and his travels in India, from the year 629 until 645 (of our era), by Houeï-li and Yen-thsong, followed by documents and geographic clarifications taken from Hiouen-thsang's original report, translated from Chinese by Stanislas Julien, member of the Institut of France]. Journal des savants [Journal of scholars]: (Mars 1855): 149-61; (Août 1855): 485-98; (Septembre 1855): 556-66; (Novembre 1855): 677-89; (Février 1856): 82-94; (Mars 1985): 161-73; (Juin 1856): 348-59; (Juillet 1856): 400-12.

Beal, Samuel. The Life of Hiuen-Tsiang, by the Shamans Hwui-Li and Yen-tsung. London: Trübner \& Co., 1888. 
- - - Si-Yu-Ki. Buddhist Records of the Western World, Translated From the Chinese of Hiuen-Tsiang (A.D. 629) 2 vols. London: Trübner, 1884.

- - . Travels of Fah-Hian and Sung-Yun. Buddhist Pilgrims from China to India (400 A.D. and 518 A.D.). London: Trübner \& Co., 1869.

Beinorius, Audrius. 'Buddhism in the Early European Imagination: A Historical Perspective'. Acta Orientalia Vilnensia 6, no. 2 (2005): 7-22.

Burnouf, Eugène. Introduction à l'bistoire du Buddhisme indien [Introduction to the history of Indian Buddhism]. Paris: Maisonneuve, 1876 (first published 1844). Translated by Katia Buffetrille and Donald S.Lopez, Jr. as Introduction to the History of Indian Buddhism (Chicago: Chicago University Press, 2010).

Cannon, Garland. The Life and Mind of Oriental Jones: Sir William Jones, the Father of Modern Linguistics. Cambridge: Cambridge University Press, 1990.

Chavannes, Édouard. Mémoire composé à l'époque de la Grande Dynastie T'ang sur les religieux éminents que allèrent chercher la Loi dans les pays d'occident par I-Tsing [Memoir written by I-Tsing during the Grand Tang Dynasty on eminent monks who went in search of the Law in the Western countries.]. Paris, E. Leroux, 1894.

- - - 'Voyage De Song Yun Dans l'Udyāna Et Le Gandhāra (518-522 P.C.)' [Song Yun's Voyage in Udyāna and Gandhāra (518-522 CE)]. Bulletin de l'École Française d'Extrême-Orient [Bulletin of the French School of the Extreme Orient] 3 (1903): 379-471.

Colebrooke, Henry Thomas. Miscellaneous Essays, Volume 1. London: Wm. H. Allen \& Co., 1837.

Cunningham, Alexander. The Ancient Geography of India, I. The Buddhist Period Including the Campaigns of Alexander, and the Travels of Hwen-Thsang. London: Trübner \& Co., 1871.

- - . Four Reports Made During the Years 1862, 1863, 1864, 1865. Simla: Government Central Press (Archaeological Survey of India, Volume I), 1871. 
Deeg, Max. 'When Peregrinus is not Pilgrim: The Chinese "Pilgrims" Records-A Revision of Literary Genre and its Context'. In Dharmayātra-Buddhist Pilgrimage in Time and Space, Christoph Cueppers \& Max Deeg, eds., 65-95. Lumbinī: Lumbinī International Research Institute, 2014.

- _ . " "Tis all here. A treasure locked": Unlocking the wonder house of Chinese Buddhist travelouges'. In Buddhism and Gandhara: An Archaeology of Museum Collections, edited by Himanshu Prabha Ray, 47-69. London: Routledge, 2018. de Jong, Jan Willem. A Brief History of Buddhist Studies in Europe and America. Tokyo: Kosei Publishing Co., 1997.

Franklin, Michael J. Orientalist Jones: Sir William Jones, Poet, Lawyer, and Linguist, 1746-1794. Oxford: Oxford University Press, 2011.

Fuchs, Walter. Huei-ch'ao's Pilgerreise durch Nordwest-Indien und Zentralasien um 726 [Huei-ch'ao's Pilgrimage through North-Western India and Central Asia around the Year of 726]. Sitzungsbericht der Preußischen Akademie der Wissenschaften, Philosophisch-Historische Klasse 30 [Session Report of the Prussian Academy of Sciences, Class of Philosophy and History], 426-69. Berlin: Verlag der Akademie der Wissenschaften, 1938.

Giles, Herbert A. The Travels of Fa-bsien (399-414 A.D.), or Record of the Buddhistic Kingdoms. Cambridge: Cambridge University Press, 1923.

Imam, Abu. Sir Alexander Cunningham and the Beginnings of Indian Archaeology. Dacca: Asiatic Society of Pakistan, 1966.

Jones, William. The Works of William Jones. 6 vols. Vol. I. London: G.G and J. Robinson, 1799.

Julien, Stanislas. 'Examen critique de quelques pages de chinois relatives à l'Inde, traduites par M. G. Pauthier, accompagné de discussions grammaticales sur certaines règles de position, qui, en chinois, jouent les mêmes rôles que les inflections dans les autres langues' [Critical study of some Chinese pages on India, translated by M.G Pautheir, accompanied by grammatical discussions on certain rules on position, which, in Chinese, play the same role as inflections in other languages]. Journal Asiatique [Asiatic Journal] ser. 3, t. 11 (Mai 1841): 401-556. 
- - - 'Art. XIX.—Extrait du livre IV des Mémoires de Hiouenthsang' [Article XIX. Excerpt from the fourth book of Hiouenthsang's memoirs]. Journal of the Royal Asiatic Society of Great Britain and Ireland 16 (January 1856): 340-45.

-_- Histoire de la vie de Hioun-Thsang et des ses voyages dans l'Inde, depuis l'an 629 jusqu'en 645, par Hoei-Li et Yen-Thsong [Story of the life of Hioun-Thsang and his travels in India, from the year 629 until 645, by Hoei-Li and Yen-Thsong]. Paris: Imprimerie impériale, 1853.

- - - Mémoires sur les contrées occidentales, traduits du Sanscrit en Chinois, en l'an 648, par Hiouen-Thsang, et du Chinois en Français [Memoirs of Western regions, translated from Sanskrit to Chinese in 648 by Hiouen-Thsang, and from Chinese to French.]. 2 tômes. Paris: Imprimerie impériale, 1857 / 58. Lassen, Christian. Indische Alterthumskunde. Erster Band:

Geographie und die älteste Geschichte [The Study of Indian Antiquity. Volume One: Geography and Antiquity]. Bonn: Verlag von H. B. König, 1847.

-_- Indische Alterthumskunde. Zweiter Band: Geschichte von Buddha bis auf die Ballabhi-und jüngere Gupta-Dynastie [The Study of Indian Antiquity. Volume Two: The History from the Buddha to the Ballabhi and Earlier Gupta Dynasty]. Bonn: Verlag von H. B. König, 1852.

_-_. Indische Alterthumskunde. Dritter Band: Geschichte des Handels und des griechisch-römischen Wissens von Indien und Geschichte des nördlichen Indiens von 319 nach Christi Geburt bis auf die Mubammedaner [The Study of Indian Antiquity. Volume Three: The History of Trade and of Graeco-Roman Knowledge of India, and the History of Northern India between 319 A.D. Until the Muslims.]. Leipzig: Verlag von L. A. Kittler, 1858.

- - - Indische Alterthumskunde. Vierter Band: Geschichte des Dekhans, Hinterindiens und des Indischen Archipels von 319 nach Christi Geburt bis auf die Mubammedaner und die Portugiesen. Nebst Umriss der Kulturgeschichte und der Handelsgeschichte dieses Zeitraums [The Study of Indian Antiquity. Volume Four: The History of Deccan, South-East Asia and the Indian 
Archipelago between 319 A.D. until the Muslims and the Portuguese, Together with an Outline of Cultural History and the History of Trade in Said Period]. Leipzig: Verlag von L. A. Kittler, 1861.

-_- Indische Alterthumskunde. Anbang zum III. und IV. Bande: Geschichte des chinesischen und arabischen Wissens von Indien [The Study of Indian Antiquity. Supplement to Vols. Three and Four: The History of Chinese and Arabian Knowledge of India]. Leipzig: Verlag von L. A. Kittler, 1862.

Legge, James. A Record of Buddhistic Kingdoms. Being an Account by the Chinese Monk Fâ-Hien of His Travels in India and Ceylon (A.D. 399-414) in Search of the Buddhist Books of Discipline. Oxford: Clarendon Press, 1886.

Leoshko, Janice. Sacred Traces: British Explorations of Buddhism in South Asia. Aldershot, Burlington: Ashgate, 2003.

Lévi, Sylvain \& Édouard Chavannes. 'L'itinéraire d'Ou-K'ong (751790)'. Journal Asiatique [Asiatic Journal] ser. 9, t. 6 (SeptembreOctobre 1895): 341-84.

Lopez, Donald. 'Buddha'. In Critical Terms for the Study of Buddhism, edited by Donald Lopez, 13-36. Chicago: The University of Chicago Press, 2005.

- - . From Stone to Flesh: A Short History of the Buddha. Chicago:

The University of Chicago Press, 2013.

- - . 'Introduction'. In Introduction to the History of Indian Buddhism, by Eugène Burnouf, 1-27. Chicago: Chicago University Press, 2010.

Neumann, Karl. 'Pilgerfahrten buddhistischer Priester von China nach Indien'. Historisch-Theologische Zeitschrift Vol. III, 2 (1833): 114-77.

- - - Review of Foe Kone Ki ou Relation des royaumes bouddhiques: Voyage dans la Tartarie, dans l'Afghanistan et dans l'Inde, execute à la fin du IVe siècle, par Chy Fa Hian. Traduit du Chinois et commentépar M. Abel Rémusat Ouvrage posthume, rev., complété, et augm. d'éclaircissements nouveaux par MM. Klaproth et Landresse [Foe Koue Ki or Relations of Buddhist Kingdoms: A voyage in Tatary, Afghanistan and in India, executed at the end of the fourth century, by Chy Fa Hian. 
Translated from Chinese and comments by M. Abel Rémusat Posthumous work, newly revised, completed, and augmented for clarity by MM. Klaproth and Landresse]. Zeitschrift für die Kunde des Morgenlandes [Journal of the Study of the Orient] 3 (1840): 105-51.

Osterhammel, Jürgen. Die Verwandlung der Welt: Eine Geschichte des 19. Jabrbunderts [The Transformation of the World: A History of the 19th Century]. München: C. H. Beck, 2009.

Osterhammel, Jürgen, and Patrick Camiller, trans. The Transformation of the World: A Global History of the Nineteenth Century. Princeton: Princeton University Press, 2014.

Prinsep, James. Essays on Indian Antiquities, Historic, Numismatic, and Paleographic of the Late James Prinsep. Edited, with notes, and additional matter by Edward Thomas. Vol. II. London: John Murray, 1858.

Rémusat, Jean-Pierre Abel. Foё Kouĕ Ki, ou, Relation des royaumes bouddhiques: voyage dans la Tartarie, dans l'Afghanistan et dans l'Inde, exécuté, à la fin du IVe siècle par Chy Fa Hian. Traduit du chinois et commenté par Abel Rémusat. Ouvrage posthume, rev., complété, et augm. d'éclaircissements nouveaux par MM. Klaproth et Landresse. Paris: Imprimerie royale, 1836. Translated by J. W. Laidlay as The Pilgrimage of Fa Hian; from the French Edition of the 'Foe Koue Ki' of MM. Rémusat, Klaproth, and Landresse. With Additional Notes and Illustrations. Calcutta: Baptist Mission Press, 1848.

Ritter, Carl. Die Erdkunde im Verbältnis zur Natur und Geschichte des Menschen oder allgemeine vergleichende Geographie als sichere Grundlage des Studiums und Unterrichts in physicalischen und historischen Wissenschaften [Geography and ist Relation to the Nature and History of Man, or: General and Comparative Geography as a Solid Foundation of the Study and Instruction of the Physical and Historic Sciences], 21 vols. Berlin: G. Reimer, 1817.

- - - Die Stupa's (Topes) oder die architectonischen Denkmale an der Indo-Baktrischen Königsstrasse und die Colosse von Bamiyan (Eine Abhandlung zur Althertumskunde des Orients) 
[The Stupas or the Architectural Monuments Along the IndoBactrian Road of Kings and the Colossi of Bamiyan (A Treatise on the Study of Oriental Antiquity)]. Berlin: Nicolai'sche Buchhandlung, 1838.

Salomon, Richard. Indian Epigraphy: A Guide to the Study of Inscriptions in Sanskrit, Prakrit, and Other Indo-Aryan Languages. New York, Oxford: Oxford University Press, 1998. Silk, Jonathan. 'The Victorian Creation of Buddhism'. Review of Almond 1988. Journal of Indian Philosophy 22, no. 2 (1994): 171-96.

Sykes, William Henry. 'Notes on the Religious, Moral, and Political State of India before the Mahomedan Invasion, chiefly founded on the Travels of the Chinese Buddhist Priest Fa Hian in India, A.D. 399, and on the Commentaries of Messrs. Rémusat, Klaproth, Burnouf, and Landresse.' Journal of the Royal Asiatic Society of Great Britain and Ireland 6, no. 12 (July 1841): 248-484.

Takakusu Junjirō. A Record of the Buddhist Religion, as Practised in India and the Malay Archipelago (AD 671-695), by I-Tsing. London: Carendon Press, 1896.

Turnour, George. An Epitome of the History of Ceylon, Compiled from Native Annals: And the First Twenty Chapters of the Mahawanso. Ceylon: Cotta Church Mission Press, 1836.

- - - The Mabávanso in Roman Characters, With the Translation Subjoined; and an Introductory Essay on Páli Buddhistical Literature. 2 vols. Ceylon: Cotta Church Press, 1837.

Walravens, Hartmut. Zur Geschichte der Ostasienwissenschaften in Europa: Abel Rémusat (1788-1832) und das Umfeld Julius Klaproths (1783-1835) [On the History of East Asian Studies in Europe: Abel Rémusat (1788-1832) and the environs of Julius Klaproth (1783-1835)]. Wiesbaden: Otto Harrassowitz, 1999. Watters, Thomas. On Yuan Chwang's Travels in India. 2 vols. London: Royal Asiatic Society, 1904.

Wilson, Horace Hayman. 'Abstract of the Content of the Dulvá, or First Portion of the Káh-gyur, from the Analysis of Mr. Alexander Csoma de Körös'. Journal of the Asiatic Society of Bengal 1, no. 1 (1832): 1-8. 
- - . 'Account of the Foe Kúe Ki, or Travels of Fa Hian in India'. Journal of the Royal Asiatic Society of Great Britain and Ireland 5, no. 9 (January 1838): 108-40.

- - - 'Lecture on the Present State of the Cultivation of Oriental Literature'. Journal of the Royal Asiatic Society of Great Britain and Ireland 13 (January 1852): 191-215.

- - . 'On Buddha and Buddhism'. Journal of the Royal Asiatic Society of Great Britain and Ireland 16 (January 1856): 229-65. (Quoted after Works by the Late Horace Hayman Wilson, Vol. II. London: Trübner \& Co., 1862: 310-78).

- - - 'Summary Review of the Travels of Hiouen Thsang, from the Translation of the Si-yu-ki by M. Julien, and the Mémoire Analytique of M. Vivien de St. Martin'. Journal of the Royal Asiatic Society of Great Britain and Ireland 17 (January 1860): 106-37.

Yuyama Akira. Eugène Burnouf: The Background to His Research into the Lotus Sutra. Hachioji: The International Research Institute for Advanced Buddhology, Soka University, 2000. 